\title{
BIOACCUMULATION OF COPPER, ZINC, CADMIUM AND LEAD BY BACILLUS SP., BACILLUS CEREUS, BACILLUS SPHAERICUS AND BACILLUS SUBTILIS
}

\author{
Antonio Carlos Augusto da Costa*; Flavia Pereira Duta \\ Universidade do Estado do Rio de Janeiro, Instituto de Química, \\ Departamento de Tecnologia de Processos Bioquímicos, Maracanã, RJ, Brasil
}

Submitted: July 17, 1999; Returned to authors for corrections: January 13, 2000; Approved: March 03, 2001

\begin{abstract}
This work presents some results on the use of microbes from the genus Bacillus for uptake of cadmium, zinc, copper and lead ions. Maximum copper bioaccumulations were $5.6 \mathrm{~mol} / \mathrm{g}$ biomass for $B$. sphaericus, $5.9 \mathrm{~mol} / \mathrm{g}$ biomass for $B$. cereus and B. subtilis, and $6.4 \mathrm{~mol} / \mathrm{g}$ biomass for Bacillus sp. Maximum zinc bioaccumulations were $4.3 \mathrm{~mol} / \mathrm{g}$ biomass for $B$. sphaericus, $4.6 \mathrm{~mol} / \mathrm{g}$ biomass for $B$. cereus, $4.8 \mathrm{~mol} / \mathrm{g}$ biomass for Bacillus $\mathrm{sp}$. and $5.0 \mathrm{~mol} / \mathrm{g}$ biomass for $B$. subtilis. Maximum cadmium bioaccumulations were $8.0 \mathrm{~mol} / \mathrm{g}$ biomass for $B$. cereus, $9.5 \mathrm{~mol} / \mathrm{g}$ biomass for B. subtilis, $10.8 \mathrm{~mol} / \mathrm{g}$ biomass for Bacillus sp. and $11.8 \mathrm{~mol} / \mathrm{g}$ biomass for $B$. sphaericus. Maximum lead biomaccumulations were $0.7 \mathrm{~mol} / \mathrm{g}$ biomass for $B$. sphaericus, $1.1 \mathrm{~mol} / \mathrm{g}$ biomass for B. cereus, $1.4 \mathrm{~mol} / \mathrm{g}$ biomass for Bacillus sp. and $1.8 \mathrm{~mol} / \mathrm{g}$ biomass for $B$. subtilis. The different Bacillus strains tested presented distinct uptake capacities, and the best results were obtained for B. subtilis and B. cereus.
\end{abstract}

Key words: bioaccumulation, Bacillus, heavy metals

\section{INTRODUCTION}

Industrialization is accelerating the deposition of heavy metals in soil and water bodies. In some ecosystems these metals can be easily incorporated by organic and inorganic fractions of the soil and by sediments. The extent of this incorporation depends on the concentration of metals and on characteristic biotic and abiotic factors. Nevertheless, in water bodies or soil, metals can be remobilized, acting as toxic elements. This way, it is essential to minimize deleterious effects of dispersion in natural waters, through the use of suitable technology-based techniques.

Conventional processes used for removal of heavy metals from industrial wastewaters include chemical precipitation, oxireduction, filtration, electrochemical techniques and sophisticated separation processes using membranes. These processes are usually expensive when heavy metals are present in moderate concentrations, such as 1 to $100 \mathrm{mg} / \mathrm{L}$ (1). This characteristic stimulates the use of alternative biotechnologies, due to their reduced cost and lower aggressiveness to the environment.
Beveridge (2) focused his studies on the microbial morphology and incorporation of heavy metals; he concluded that the interaction between heavy metals and surface biological structures is inevitable. This surface accumulation occurs through chemical reactions such as complexation and ion-exchange with structural compounds present in the surface of microbes and other organisms (3). Incorporation is based on the polysaccharide composition of each particular organism, and is highly variable among distinct genera and even strains from the same species.

Two particular groups of metals are of interest in this case: valuable metals, such as gold, platinum and silver, and toxic heavy metals, specially those from mining metallurgical activities $(4,5,6)$.

Some basic points about the surface structures of Grampositive and Gram-negative bacteria should be briefly presented. A characteristic component of Gram-positive cells are teichoic acids and acids associated to the cell wall, whose phosphate groups are key components for the uptake of metals. The literature reports several studies on the interaction of heavy

\footnotetext{
* Corresponding author. Mailing address: Universidade do Estado do Rio de Janeiro, Instituto de Química, Departamento de Tecnologia de Processos Bioquímicos, Rua S. Francisco Xavier, 524 - Pavilhão Haroldo Lisboa da Cunha, CEP 20550-013, Maracanã, RJ, Brasil
} 
metals with bacterial surfaces, but just a few works consider these interactions at the molecular level $(2,3)$. Thus, a detailed investigation of the chemical structures of bacterial cells and the understanding of the mechanism involved in the interaction is still missing in the study of the bioaccumulation process. The rationale for using Bacillus cells to study the uptake of heavy metal elements is the previous knowledge that Gram-positive cells accumulate a much higher amount of heavy metals than Gram-negative cells. Carboxyl groups are the main agents in the uptake of heavy metals. The sources of these carboxyl groups are the teichoic acids, associated to the peptidoglycan layers of the cell wall.

In a broad review about the ultrastructure of the bacterial wall, surface structures were deeply detailed, providing a better understanding of the possible reaction sites $(3,4)$.

The purpose of the present work was to investigate the ability of four Bacillus species, namely, Bacillus sp., B. cereus, B. sphaericus and $B$. subtilis to accumulate copper, cadmium, zinc and lead. The objective is the selection of the best microbial species to be used in association with waste biomaterials to turn a batch process into a continuous process, with the advantage of suppressing costs of immobilization of the microbial cells.

\section{MATERIALS AND METHODS}

\section{Microbial strains}

In the present study four microbial species were used: Bacillus sp., B. cereus, B. sphaericus and B. subtilis. All these strains were obtained from the culture collection of the Department of Biochemical Processes Technology from Rio de Janeiro State University (UERJ). Strains were maintained in agar slants containing nutrient broth. They were transferred weekly to new medium in order to keep metabolic activity and checked for purity by microscopic examination.

\section{Culture medium}

Cells were cultured in nutrient broth with the following composition: beef extract (3.0 g), peptone (10.0 g), dissodium phosphate $(1.0 \mathrm{~g})$, sodium chloride $(5.0 \mathrm{~g})$, dissolved in one liter of distilled water. Final $\mathrm{pH}$ was around 7.4-7.6. The medium was autoclaved at $121^{\circ} \mathrm{C}$ for 20 minutes. Cultures were mantained in agar slants (nutrient broth plus $30 \mathrm{~g} / \mathrm{L}$ agar).

\section{Cultivation of the cells}

Cells were inoculated in nutrient broth (100 mL/flask) and kept under agitation in a rotary shaker, at $80 \mathrm{rpm}$, for 48 hours at $27 \pm 2^{\circ} \mathrm{C}$. Cells to be used in bioaccumulation experiments were separated by centrifugation.

\section{Quantification of the cell}

Cells were quantified by direct weighing of the biomass, after drying at $105^{\circ} \mathrm{C}$ for 24 hours.

\section{Solutions of metals}

Solutions of copper, cadmium, zinc and lead sulphates were prepared in distilled water. Copper solutions presented the following concentrations: $1.7,8.8,17.6,44.0$ and $88.0 \mathrm{mg} / \mathrm{L}$, namely Conc. 1, 2, 3, 4 and 5, respectively. Zinc solutions presented the following concentrations: 1.2, 5.7, 11.5, 28.7 and $57.5 \mathrm{mg} / \mathrm{L}$, namely Conc. 1, 2, 3, 4 and 5, respectively. Cadmium solutions presented the following concentrations: 4.4, 22.0, 44.0, 110.0 and $220.0 \mathrm{mg} / \mathrm{L}$, namely Conc. 1, 2, 3, 4 and 5, respectively. Finally, lead solutions presented the following concentrations: 1.2, 5.8, 11.7, 29.2 and 58.5 mg/L, namely Conc. 1, 2, 3, 4 and 5 , respectively. All solutions were analyzed by atomic absorption spectrometry (Perkin-Elmer Analyst Model AA-300).

\section{Experiments of bioaccumulation}

Experiments of heavy metals bioaccumulation were done in Erlenmeyer flasks containing $100 \mathrm{~mL}$ of each heavy metal solution and $16.0 \pm 1.0 \mathrm{mg}$ of cells. To ensure equilibrium, cells and metal solution were maintained in contact for 24 hours, under constant agitation, at $27 \pm 2^{\circ} \mathrm{C}$. In all experiments, cells were obtained from only one cultivation and collected from the same flask at the same growth stage. Microscopic observations revealed that cells did not grow or were lysed after incubation in the metal solutions. After 24 hours, cells were separated from the medium and residual metal concentrations were monitored by atomic absorption spectrometry. Experiments were done in triplicate.

\section{RESULTS AND DISCUSSION}

Fig. 1 presents the results of bioaccumulation of copper, zinc, cadmium and lead, when Bacillus sp. was used. Bioaccumulation ranged from 0.2 to $6.4 \mathrm{~mol} / \mathrm{g}$ biomass for copper; from 0 to 4.8 $\mathrm{mol} / \mathrm{g}$ biomass for zinc; 0.2 to $10.8 \mathrm{~mol} / \mathrm{g}$ biomass for cadmium; and, from 0.1 to $1.4 \mathrm{~mol} / \mathrm{g}$ biomass for lead. Results are expressed as $\mathrm{mol} / \mathrm{g}$ in order to allow a direct comparison of results for the different metals.

An increasing uptake pattern can be observed for all the metals (Fig. 1). Saturation of biomass by metals was not observed, indicating that available sites probably exist. More concentrated metal solutions should be used to reach saturation. However, determination of saturation levels was not the purpose of the present investigation, but the determination of the potential ability of the cells to accumulate heavy metals to be used as metal concentrators in wastewater treatment, immobilized on the surface of waste biomaterials. Classical adsorption equations were not here used, because probably uptake was not restricted to surface phenomena, once viable cells were here used. Any metabolic activity could be in action during the uptake.

Fig. 1 also shows a selective uptake: cadmium > copper > zinc $>$ lead.

Fig. 2 represents metals uptake by B. cereus. The same qualitative results described for Bacillus sp. can be observed. 
However, quantitative bioaccumulation ranged from 0.1 to 5.9 $\mathrm{mol} / \mathrm{g}$ biomass for copper; from 0 to $4.6 \mathrm{~mol} / \mathrm{g}$ biomass for zinc; from 0.2 to $8.0 \mathrm{~mol} / \mathrm{g}$ biomass for cadmium; and, from 0.1 to 1.1 $\mathrm{mol} / \mathrm{g}$ biomass for lead.

Fig. 3 shows bioaccumulation of metals by B. sphaericus. Uptake levels ranged from 0.2 to $5.6 \mathrm{~mol} / \mathrm{g}$ biomass for copper; from 0 to $4.3 \mathrm{~mol} / \mathrm{g}$ biomass for zinc; from 0.2 to $11.8 \mathrm{~mol} / \mathrm{g}$ biomass for cadmium; and from 0.1 to $0.7 \mathrm{~mol} / \mathrm{g}$ biomass for lead.

Results obtained when B. subtilis was used are described in Fig. 4. The same profile of metal accumulation was observed, however distinct uptake patterns were obtained: from 0.2 to 5.9 $\mathrm{mol} / \mathrm{g}$ biomass for copper; from 0.1 to $5.0 \mathrm{~mol} / \mathrm{g}$ biomass for zinc; from 0.2 to $9.5 \mathrm{~mol} / \mathrm{g}$ biomass for cadmium; and from 0.1 to $1.8 \mathrm{~mol} / \mathrm{g}$ biomass for lead.

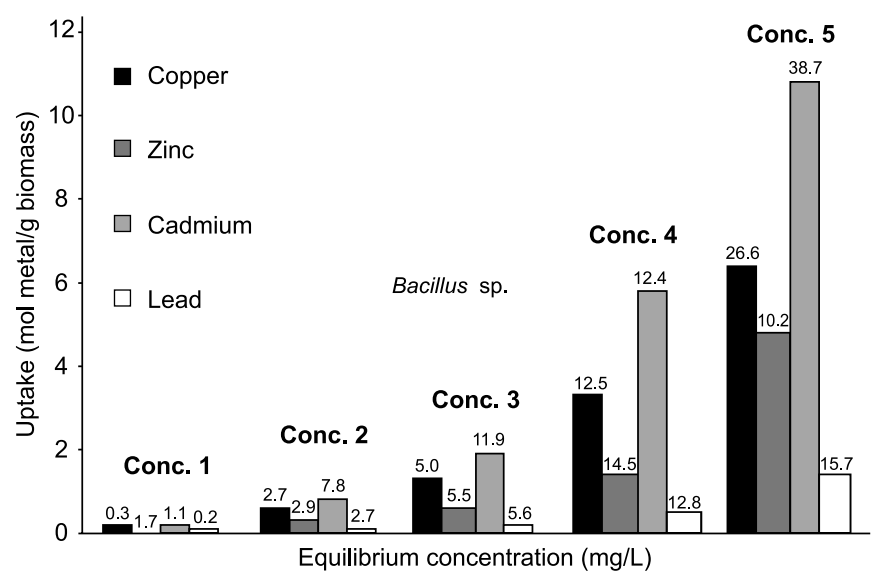

Figure 1. Copper, zinc, cadmium and lead bioaccumulation by Bacillus sp. (Values plotted on the bars correspond to metal equilibrium concentrations).

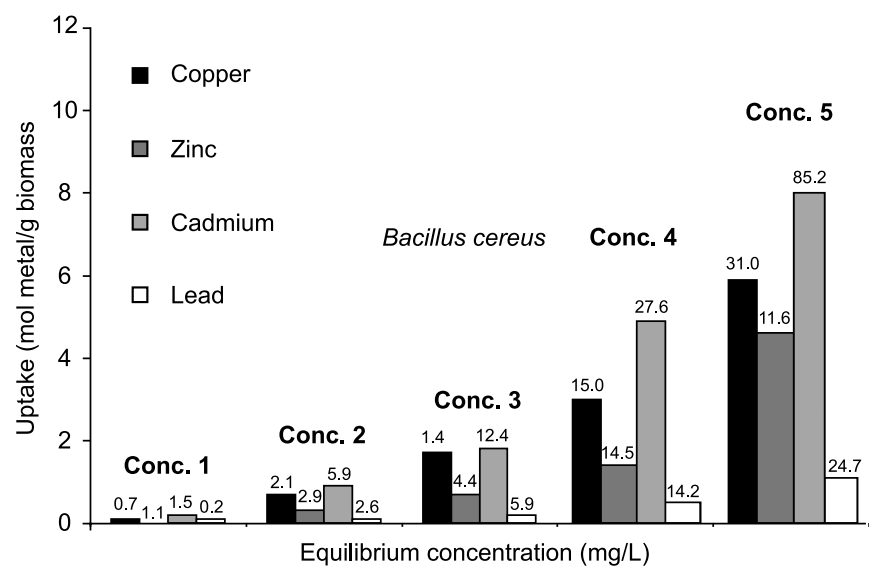

Figure 2. Copper, zinc, cadmium and lead bioaccumulation by Bacillus cereus (Values plotted on the bars correspond to metal equilibrium concentrations).

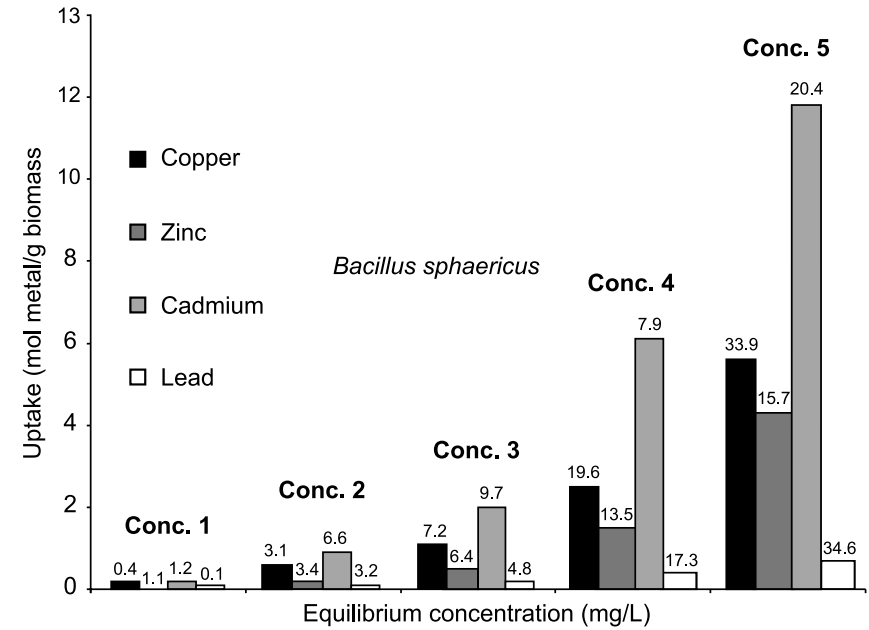

Figure 3. Copper, zinc, cadmium and lead bioaccumulation by Bacillus sphaericus (Values plotted on the bars correspond to metal equilibrium concentrations).

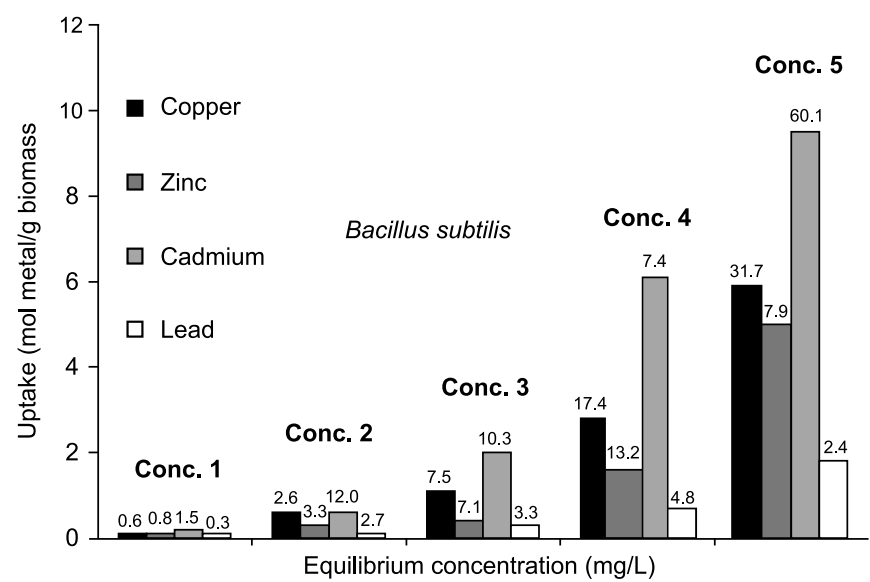

Figure 4. Copper, zinc, cadmium and lead bioaccumulation by Bacillus subtilis (Values plotted on the bars correspond to metal equilibrium concentrations).

In order to select a suitable Bacillus strain for further studies, a simple mathematical analysis was performed with the overall results obtained in the four groups of experiments. The first set of four bars from Figs. 1 to 4 were compared and the most suitable strain to accumulate the metals at each concentration level was detected. The same comparison was done with the other sets of bars in Figs. 1 to 4 . The results of these comparisons are presented in Table 1. For bioaccumulation of copper Bacillus sp. produced two results that were statistically distinct from the average values for all microbial cells; $B$. cereus presented four values that differed significantly from the average; B. sphaericus and B. subtilis presented two of these values. Based 
Table 1. Copper, zinc, cadmium and lead bioaccumulation by the four Bacillus strains indicating statistically significant distinct results.

\begin{tabular}{|c|c|c|c|c|c|}
\hline \multicolumn{6}{|c|}{ Bioaccumulation of copper (mol/g biomass) } \\
\hline \multicolumn{6}{|c|}{ Average values } \\
\hline Strain & $1^{\text {st }}$ set of bars & $2^{\text {nd }}$ set of bars & $3^{\text {rd }}$ set of bars & $4^{\text {th }}$ set of bars & $5^{\text {th }}$ set of bars \\
\hline \multicolumn{6}{|c|}{ Individual values } \\
\hline Bacillus sp. & 0.2 & 0.6 & 1.3 & 3.3 & 6.4 \\
\hline B. cereus & 0.1 & 0.7 & 1.7 & 3.0 & 5.9 \\
\hline B. subtilis & 0.1 & 0.6 & 1.1 & 2.8 & 5.9 \\
\hline
\end{tabular}

Bioaccumulation of zinc (mol/g biomass)

\begin{tabular}{lccccc}
\hline \multicolumn{5}{c}{ Average values } \\
\hline Strain & $\begin{array}{c}1^{\text {st }} \text { set of bars } \\
0.01 \pm 0.02\end{array}$ & $\begin{array}{c}2^{\text {nd }} \text { set of bars } \\
0.25 \pm 0.05\end{array}$ & $\begin{array}{c}3^{\text {rd }} \text { set of bars } \\
0.55 \pm 0.12\end{array}$ & $\begin{array}{c}4^{\text {th }} \text { set of bars } \\
1.47 \pm 0.09\end{array}$ & $\begin{array}{c}5^{\text {th }} \text { set of bars } \\
4.67 \pm 0.29\end{array}$ \\
\hline Individual values & 0 & 0.3 & 0.6 & 1.4 & 1.4 \\
\hline Bacillus sp. & 0 & 0.3 & 0.7 & 1.5 & 4.8 \\
B. cereus & 0 & 0.2 & 0.5 & 1.6 & 4.3 \\
B. sphaericus & 0 & 0.2 & 0.4 & 5.0 \\
B. subtilis & 0.04 & & & \\
\hline
\end{tabular}

Bioaccumulation of cadmium (mol/g biomass)

\begin{tabular}{lccccc}
\hline \multicolumn{5}{c}{ Average values } \\
\hline Strain & $\begin{array}{c}1^{\text {st }} \text { set of bars } \\
0.2 \pm 0\end{array}$ & $\begin{array}{c}2^{\text {nd }} \text { set of bars } \\
0.82 \pm 0.17\end{array}$ & $\begin{array}{c}3^{\text {rd }} \text { set of bars } \\
1.92 \pm 0.09\end{array}$ & $\begin{array}{c}4^{\text {th }} \text { set of bars } \\
5.72 \pm 0.56\end{array}$ & $\begin{array}{c}5^{\text {th }} \text { set of bars } \\
10.02 \pm 1.64\end{array}$ \\
\hline Individual values & & & 1.9 & 5.8 & 10.8 \\
\hline Bacillus sp. & 0.2 & 0.8 & 1.8 & 4.9 & 8.0 \\
B. cereus & 0.2 & $\mathbf{1 . 0}$ & 2.0 & 6.1 & 6.1 \\
B. sphaericus & 0.2 & 0.9 & 2.0 & 9.5 \\
B. subtilis & 0.2 & 0.6 & & 6 \\
\hline
\end{tabular}

Bioaccumulation of lead ( $\mathrm{mol} / \mathrm{g}$ biomass)

\begin{tabular}{lccccc}
\hline \multicolumn{5}{c}{ Average values } \\
\hline Strain & $\begin{array}{c}\text { st } \\
\text { set of bars } \\
0.1 \pm 0\end{array}$ & $\begin{array}{c}2^{\text {nd }} \text { set of bars } \\
0.1 \pm 0\end{array}$ & $\begin{array}{c}3^{\text {rd }} \text { set of bars } \\
0.22 \pm 0.05\end{array}$ & $\begin{array}{c}4^{\text {th }} \text { set of bars } \\
0.55 \pm 0.17\end{array}$ & $\begin{array}{c}5^{\text {th }} \text { set of bars } \\
1.25 \pm 0.46\end{array}$ \\
\hline Individual values & \multicolumn{7}{c}{. } & 0.1 & 0.5 & 1.4 \\
\hline Bacillus sp. & 0.1 & 0.1 & 0.2 & 0.5 & 1.1 \\
B. cereus & 0.1 & 0.1 & 0.2 & 0.4 & 0.7 \\
B. sphaericus & 0.1 & 0.1 & 0.3 & 0.8 & 1.8 \\
B. subtilis & 0.1 & &
\end{tabular}

Shadowed rectangles correspond to statistically significant distinct results.

on these results, B. cereus was selected as the best copper biosorber. If the same evaluation is performed for the remaining results from Table $1, B$. subtilis was the best zinc accumulator, $B$. cereus the best cadmium accumulator and B. subtilis, again, the best lead biosorber. Due to their poor performance, Bacillus sp. and B. sphaericus will not be included in future experiments. The selected Bacillus strains can be used, in the future, for heavy metals removal, immobilized on waste biomaterials.

\section{RESUMO}

\section{Bioacumulação de cobre, zinco, cádmio e chumbo por Bacillus sp., Bacillus cereus, Bacillus sphaericus e Bacillus subtilis}

Este trabalho apresenta resultados de acumulação dos íons metálicos cádmio, zinco, cobre e chumbo por bactérias do 
gênero Bacillus. A bioacumulação máxima de cobre foi 5,6 $\mathrm{mol} / \mathrm{g}$ biomassa para $B$. sphaericus, $5,9 \mathrm{~mol} / \mathrm{g}$ biomassa para B. cereus e B. subtilis, e $6,4 \mathrm{~mol} / \mathrm{g}$ biomassa para Bacillus sp.. A bioacumulação máxima de zinco foi $4,3 \mathrm{~mol} / \mathrm{g}$ biomassa para $B$. sphaericus, $4,6 \mathrm{~mol} / \mathrm{g}$ biomassa para $B$. cereus, 4,8 $\mathrm{mol} / \mathrm{g}$ biomassa para Bacillus sp. e 5,0 mol/g biomassa para B. subtilis. A bioacumulação máxima de cádmio foi $8,0 \mathrm{~mol} /$ g biomassa para $B$. cereus, $9,5 \mathrm{~mol} / \mathrm{g}$ biomassa para $B$. subtilis, 10,8 mol/g biomassa para Bacillus sp. e 11,8 mol/g biomassa para $B$. sphaericus. A bioacumulação máxima de chumbo foi $0,7 \mathrm{~mol} / \mathrm{g}$ biomassa para $B$. sphaericus, $1,1 \mathrm{~mol} /$ g biomassa para B. cereus, $1,4 \mathrm{~mol} / \mathrm{g}$ biomassa para Bacillus sp. e $1,8 \mathrm{~mol} / \mathrm{g}$ biomassa para $B$. subtilis. As distintas linhagens de Bacillus testadas apresentaram variáveis capacidades de carregamento de íons metálicos, sendo os melhores resultados aqueles obtidos com o emprego de $B$. subtilis e B. cereus.

Palavras-chave: bioacumulação, Bacillus, metais pesados

\section{REFERENCES}

1. Da Costa, A.C.A. An emerging biotechnology for metal containing waste water treatment. Série Tecnologia Ambiental 17, MCT-CNPq-CETEM, 100p.

2. Beveridge, T.J. Role of cellular design in bacterial metal accumulation and mineralization. Ann. Rev. Microbiol., 43:147-171, 1989.

3. Da Costa, A.C.A. Chemical interactions between mercurial species and surface biomolecules from structural components of some biological systems. In: Ebinghaus, W.; Lacerda, L.D. and Salomons, W. (eds.). Mercury Contaminated Sites: Risk Assessment and Solutions, Environmental Science Series, Chapter I-8, Springer-Verlag, Heildelberg, 1999, pp.159-178.

4. Da Costa, A.C.A.; de França, F.P. Cadmium uptake by biosorbent seaweeds: adsorption isotherms and process conditions. Sep. Sci. Technol., 31:23732393, 1996

5. Kuyucak, N.; Volesky, B. Biosorption by algal biomass. In: Volesky, B. (ed.). Biosorption of heavy metals, Boca Raton, Miami, 1990.

6. Volesky, B. Advances in biosorption of metals: selection of biomass types. FEMS Microbiol. Rev., 14:291-302, 1994.

7. Da Costa, A.C.A.; Tornovsky, J. Continuous accumulation of ionic copper in fixed-bed bioreactors. V Encuentro del Hemisferio Sur sobre Tecnologia Mineral, Buenos Aires, Argentina, 1997.

8. Da Costa, A.C.A.; de França, F.P. Biosorption of zinc, cadmium, and copper by a brown seaweed (Sargassum sp.) in continuous fixed-bed laboratory reactors. Bioseparation 6:335-341, 1997. 